\title{
Exchange Rate Pass-Through over the Business Cycle in Singapore
}

Joey Chew, Sam Ouliaris, and

Siang Meng Tan 


\title{
IMF Working Paper
}

IMF Institute

\section{Exchange Rate Pass-Through over the Business Cycle in Singapore}

\author{
Prepared by Joey Chew, Sam Ouliaris, and Siang Meng Tan ${ }^{1}$
}

Authorized for distribution by Ling Hui Tan

June 2011

\begin{abstract}
This Working Paper should not be reported as representing the views of the IMF nor the Monetary Authority of Singapore (MAS). The views expressed in this Working Paper are those of the author(s) and do not necessarily represent those of the IMF, MAS or IMF and/or MAS policy. Working Papers describe research in progress by the author(s) and are published to elicit comments and to further debate.
\end{abstract}

This paper investigates exchange rate pass-through in Singapore using band-pass spectral regression techniques, allowing for asymmetric effects over the business cycle. First stage passthrough is estimated to be complete and relatively quick, confirming existing views that the exchange rate provides an effective tool to moderate imported inflation in Singapore. Asymmetric pass-through effects over the business cycle are also detected, with importers passing on a smaller share of exchange rate movements during boom periods as compared to recessions. This result suggest that Singapore's exchange rate policy could afford to "lean against the wind," especially during cyclical expansions.

JEL Classification Numbers: $\quad$ E3, E5, F3, F4

Keywords: $\quad$ Exchange Rate Pass-Through, import prices, inflation, Singapore Author’s E-Mail Address: $\quad$ souliaris@imf.org, joeychews@,gmail.com, smtan@mas.gov.sg

\footnotetext{
${ }^{1}$ Siang Meng Tan is with the MAS (Economic Policy Department). Joey Chew is a former employee of the MAS and is presently reading towards her Master of Finance at the University of Cambridge. This paper has benefited from comments by Marco Cipriani, Rodrigo Cubero, and participants of the INS seminar series. The usual disclaimer applies.
} 


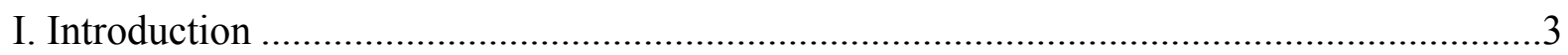

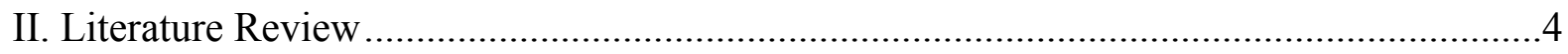

III. First Stage Exchange Rate Pass-Through .....................................................................5

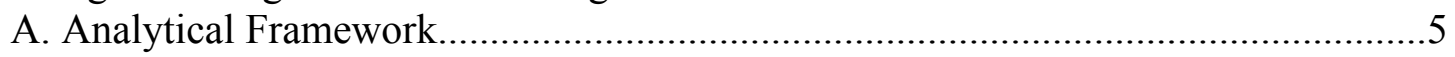

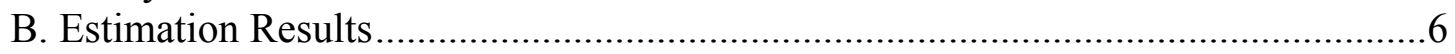

C. Pass-Through over the Business Cycle ….................................................... 7

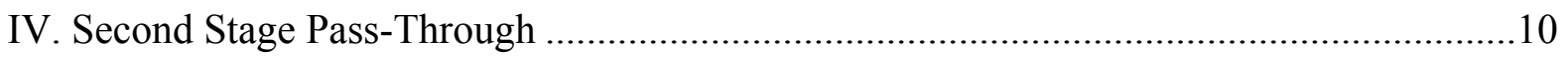

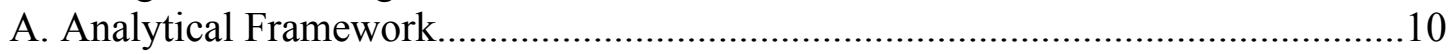

B. Estimation Results.................................................................................... 11

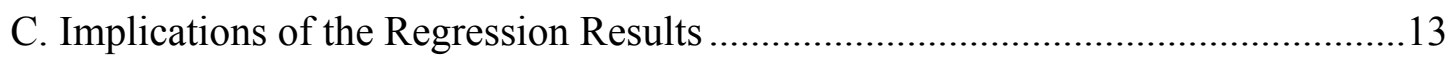

D. Asymmetric Pass-Through Effects Over the Business Cycle ................................14

V. Cumulative Impact Of The Two Stages And Implications For Monetary Policy ..............16

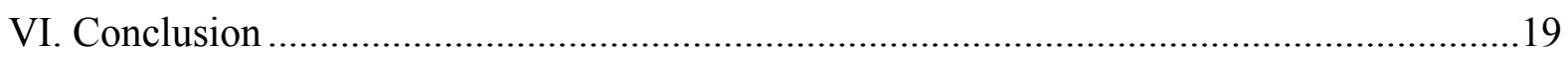

\section{TABLES}

Table 1. Estimates of the Long-run Coefficients, 1980:3 -2010:3 …......................... 7

Table 2. Exchange Rate Pass-Through Estimates Over the Business Cycle, 1980:3 -

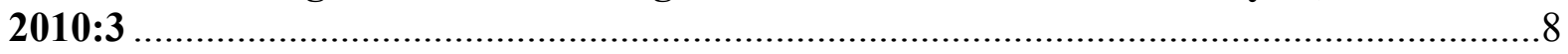

Table 3. Asymmetric Pass-Through over the Business Cycle, 1980:3 - 2010:3 ............10

Table 4. Long-Run Pass-Through to Consumer Prices, 1991:1-2007:4 ......................11

Table 5. Second Stage Pass-Through, Error Correction Estimation 1991:1 - 2007:4 ...12

Table 6. Short-Run Second Stage Pass-Through in Singapore, 2000:3-2007:4 ............12

Table 7. Possible Asymmetric Outcomes .......................................................... 15

Table 8. Results of Second Stage Asymmetric Pass-Through 2000:3-2007:4 ............. 15

\section{FIGURES}

Figure 1. Response Profile of the Consumer Price Index and IPI...............................13

Figure 2. Percentage Deviation in Consumer Price Index for a .................................17

Figure 3. Percentage Deviation in IPI and Consumer Price Index for ......................... 18

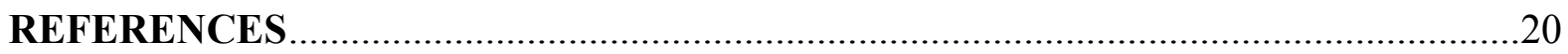




\section{INTRODUCTION}

Changes in the nominal exchange rate affect domestic consumer prices through two channels in Singapore: via the domestic prices of imported goods, or classic exchange rate pass-through; and by influencing the profit margin of exporters, which in turn affects the level of resource utilization and hence domestic price pressures. ${ }^{2}$

Classic exchange rate pass-through typically has two stages. In the first stage, changes in the nominal exchange rate are reflected in the prices of imports in local currency terms. These changes are then passed on - in whole or in part - to the consumer in the second stage. For the first stage, MAS (2001c) concluded that exchange rate pass-through is complete, with exchange rate changes taking less than four quarters to reflect themselves in the local price of imported goods. In contrast, second stage pass-through was found to be more sluggish, with changes in domestic import prices having a far more muted impact on consumer prices.

The aim of this paper is to update these estimates for Singapore and extend the analysis by assessing whether there are asymmetric pass-through effects over the business cycle. The empirical results, which are based on a new approach to estimating the business cycle components of non-stationary series (see Corbae and Ouliaris, 2006) and band-pass spectral regression techniques, imply that in the first stage importers pass on a smaller share of the cost savings (increases) arising from a stronger (weaker) exchange rate during an upturn (downturn). Moreover, in the second stage, retailers tend to be more aggressive in passing on import cost increases during strong economic conditions.

The empirical results have two implications for Singapore's exchange rate policy, which since 1981 has been centered on the management of the nominal effective exchange rate (S\$NEER) to promote price stability. ${ }^{3}$ First, the results confirm that the exchange rate continues to be an effective tool in curbing imported price inflation, as the effects of a change in the exchange rate are fully passed on to domestic import prices within a year. Second, in view of the asymmetric pass-through effects, Singapore's monetary/exchange rate policy could afford to "lean against the wind" during robust cyclical expansions to moderate inflation. The case for doing so is strengthened by the fact that its cyclical fluctuations are positively associated with the global business cycle and hence rising foreign prices.

\footnotetext{
${ }^{2}$ See MAS (2008a) for a stylized description of the price determination mechanism in Singapore.

${ }^{3}$ MAS (2001a) and Khor, Robinson and Lee (2004) provide more information on the exchange rate policy regime in Singapore.
} 
This paper is organized as follows. Section 2 presents a brief survey of the exchange rate pass-through literature. Sections 3 and 4 present the empirical results for the first and second stage pass-through, respectively. Asymmetric pass-through effects for the two stages are also separately modeled and estimated. Section 5 combines the two stages into a single empirical model and illustrates the overall pass-through transmission via simulations. Section 6 concludes.

\section{LITERATURE REVIEW}

The empirical literature on exchange rate pass-through is vast, with most of the research focused on the relationship between the exchange rate and import prices, i.e., first stage pass-through. Second stage pass-through, which involves the impact of a change in import prices on consumer prices, is seldom studied in isolation. Rarely does the literature examine pass-through over the business cycle. The aim of this paper is to fill this gap.

First stage pass-through is complete when the change in the exchange rate is reflected fully in domestic import prices. This phenomenon tends to occur in small, open economies where importers are usually price-takers. For example, Dwyer and Leong (2001) find complete pass-through for Australia and MAS (2001c) reports similar results for Singapore. ${ }^{4}$

First stage pass-through tends to be incomplete for industrial countries. For example, Campa and Goldberg (2005) find average (long-run) pass-through elasticities of approximately 64 percent in their study of import prices for a sample of 23 OECD countries in the post Bretton-Woods period. This result is similar to the estimate for the euro-area reported in Campa, Goldberg and Gonzalez-Minguez (2005).

Several econometric studies report evidence of a declining exchange rate pass-through in industrial countries, commencing around the early 1990s. For example, Marazzi and Sheets (2007) find that for the 1990s a one percent depreciation in the US dollar leads to a 0.2 percent increase in US import prices, down from 0.5 percent in the 1970s and 1980s. Results from Bailliu and Fujii (2004) also suggest a significant decline in first stage passthrough since 1990. They use a panel of 11 industrial countries that includes the US, UK and Australia.

Several hypotheses have been put forward to explain this decline in exchange rate passthrough. Taylor (2000) argues that in a stable, low inflation environment backed by a credible inflation-targeting monetary policy, firms reduce the extent to which they pass on exchange rate-related cost increases. Devereux and Yetman (2002) argue that the costs of maintaining fixed prices (namely, forgone profits) tend to be much greater than the menu costs of price changes when inflation is high, suggesting that exchange rate pass-through should increase with the rate of inflation. Dornbusch (1987) argues that the decline in

\footnotetext{
${ }^{4}$ Not all the small open economies experience complete first stage pass-through; Liu and Tsang (2008), for example, find that Hong Kong's first stage pass-though is incomplete, with the estimated long-run passthrough elasticity at 65 percent.
} 
exchange rate pass-through since the 1980s largely reflects improvements in competitive conditions. According to Marazzi and Sheets (2007), the effects of direct competition or the threat of potential competition with China has caused exporters from other countries to be more hesitant to shift their dollar denominated prices. Olivei (2002) postulates that the larger presence of multilateral corporations has led to a decline in exchange rate passthrough, owing to the prevalence of intra-company transfer pricing, which is less responsive to exchange rate movements than prices based on arm's length trade. Campa and Goldberg (2005) suggest that the decline in first stage pass-through could reflect a shift in the import bundle away from energy and raw materials toward more differentiated manufactured goods whose prices are less sensitive to exchange rate movements.

Lastly, the input mix of traded goods could also explain the phenomenon of low exchange rate pass-through to consumer prices. Engel (2002) identifies the existence of local cost components (e.g., costs for nontraded services such as labor) in traded goods as a source of incomplete exchange rate pass-through to consumer prices. Imported goods contain value added from domestic distribution services such as transportation, wholesaling and retailing. The transmission from a change in the exchange rate to the final consumer price will therefore not be one-to-one even in the long-run.

\section{First Stage EXchange Rate Pass-Through}

\section{A. Analytical Framework}

This paper assesses the degree of exchange rate pass-through using the following standard long-run model:

$$
I P I=\frac{(F W P I)^{\alpha}}{(E X R)^{\beta}}, \text { with } 0 \leq \alpha, \beta<1
$$

In equation 1.1, IPI denotes the domestic imported price index, FWPI is the foreign wholesale price index, and EXR is the Singapore dollar nominal effective exchange rate (S\$NEER). Under this specification, complete first stage pass-through in the long-run occurs if $\beta=1$.

To estimate $\beta$, a logarithmic transformation is applied to equation (1.1), yielding:

$$
\text { ipi }_{t}=\varphi+\alpha f w p i_{t}+\lambda e x r_{t}, \text { with } \lambda=-\beta, 0 \leq \alpha<1 \text {, and }-1 \leq \lambda \leq 0
$$

where $\alpha$ and $\lambda$ are the elasticities of domestic import prices with respect to foreign import prices and the exchange rate, respectively. For a small, open economy such as Singapore, first stage pass-through is expected to be complete, i.e., $\lambda=-1$. 


\section{B. Estimation Results}

All the series in equation 1.2 were found to be consistent with the unit root hypothesis using the Augmented Dickey-Fuller (ADF) test and the frequency domain test (FD) developed in Corbae and Ouliaris (2006), which assumes stationarity under the null (Table B.1). ${ }^{5}$ Residual-based tests for cointegration and the Johansen (1988) eigen-based procedure suggest the existence of a long-run relationship (Table B.2).

Equation 1.2 can therefore be estimated using Johansen's vector-error correction methodology for cointegrated systems. The parameter estimates for equation 1.2, obtained using quarterly data spanning 1980:3 to 2010:3 and two lags in the VECM, are shown in Table 1 , together with estimates with $\lambda$ constrained to -1 . They suggest a long-run passthough elasticity of 0.93 , and that the null hypothesis of $\lambda=-1$, or a long-run pass-through of unity, cannot be rejected. By contrast, the pass-through of foreign prices to domestic import prices is significantly different from one and hence incomplete-a one percent increase in the foreign price increases domestic import prices by only 0.70 percent (on average) in the long run. This result is most likely due to Singapore's well-diversified import sources. A single foreign producer might be constrained in passing on the full extent of a price increase to the Singapore market for fear of losing market share to competitors.

Lastly, the null hypothesis of weak exogeneity between the foreign wholesale price index, the nominal exchange rate and domestic imported prices cannot be rejected. The p-value for this hypothesis (together with the restriction $\lambda=-1$ ) is 0.2128 . Consequently, there is evidence to suggest that both the nominal exchange rate and the wholesale price index do not respond to the disequilibrium in the long-run relation for import prices.

Given the above findings, the constrained version of equation 1.2 can be embedded within a single equation error-correction regression to explain short-run movements in domestic import prices, namely:

$$
\begin{aligned}
& \Delta i p i_{t}=\beta_{0}+\beta_{1}\left(\text { ipi }_{t-1}-0.7295 f w p i_{t-1}+\operatorname{exr}_{t-1}\right)+\sum_{i=0}^{k} \beta_{2 i} \Delta \operatorname{exr}_{t-i}+\sum_{i=0}^{j} \beta_{3 i} \Delta f w p i_{t-i} \\
& +\sum_{i=1}^{l} \beta_{4 i} \Delta i p i_{t-i}+\varepsilon_{t}
\end{aligned}
$$

The error-correction parameter estimate of 0.18 (see Table 1(b)) suggests that full passthrough occurs in within 6 quarters.

\footnotetext{
${ }^{5}$ See appendix A for details of the data sources.
} 
Table 1. Estimates of the Long-run Coefficients, 1980:3 -2010:3

\section{(a) Long-Run Cointegrating Equation}

\begin{tabular}{|c|c|c|c|}
\hline Variable & Coefficient & Std. Err. & t-stat \\
\hline$f w p i_{t}$ & $\alpha=0.6929$ & 0.0787 & 8.8040 \\
\hline $\operatorname{exr}_{t}$ & $\lambda=-0.9294$ & 0.0820 & -11.339 \\
\hline \multirow[t]{2}{*}{ Restrictions } & \multicolumn{3}{|c|}{$\begin{array}{l}\text { LR Test for Binding Restriction } \\
\text { Null hypothesis - Restriction is binding }\end{array}$} \\
\hline & \multicolumn{2}{|c|}{\begin{tabular}{|l|l|} 
Chi-square (1) & \\
\end{tabular}} & p-value \\
\hline$\alpha=1$ & \multirow{2}{*}{\multicolumn{2}{|c|}{$\begin{array}{l}6.6329 \\
0.6412\end{array}$}} & 0.0100 \\
\hline$\lambda=-1$ & & & 0.4233 \\
\hline \multicolumn{4}{|c|}{ Estimates of the Long-run Equation with $\lambda$ constrained to -1} \\
\hline Variable & Coefficient & Std. Err. & t-stat \\
\hline$f w p i_{t}$ & $\alpha=0.7295$ & 0.02312 & 31.5492 \\
\hline $\operatorname{exr}_{t}$ & $\lambda=-1$ & - & - \\
\hline
\end{tabular}

(b) Error-Correction Model

\begin{tabular}{|c|c|c|c|c|}
\hline \multicolumn{5}{|c|}{ Dependent Variable : $\Delta \log \left(\right.$ ipi $\left._{t}\right)$} \\
\hline Variable & Coefficient & Std. Err. & t-stat & p-value \\
\hline Error-correction term & -0.1865 & 0.0414 & -4.5107 & 0.0000 \\
\hline Constant & $0.817 \mathrm{E}-03$ & $0.222 \mathrm{E}-02$ & -0.3677 & 0.7138 \\
\hline 2008 Crisis & -0.1195 & 0.0157 & -8.2096 & 0.0000 \\
\hline \multicolumn{5}{|c|}{ Diagnostic Test/Fit of Model } \\
\hline Adjusted R-squared & \multicolumn{5}{|c|}{0.5650} \\
\hline
\end{tabular}

The parameter estimates were obtained from a standard VECM model with 2 lags and a single co-integrating vector. The model includes a dummy variable for 2008:4 to deal with nonstandard volatility arising from the 2007 financial crisis.

\section{Pass-Through over the Business Cycle}

The existence of asymmetric pass-through effects over the business cycle can be assessed using the business cycle components of the variables and the following linear regression equation:

$$
c_{l}^{h}\left(I P I_{t}\right)=\delta_{1} c_{l}^{h}\left(E X R_{t}\right)+\delta_{2} c_{l}^{h}\left(F W P I_{t}\right)+\varepsilon_{t}
$$


where the operator $c_{l}^{h}()$ refers to the cyclical components of the variable in the [low, high] frequency range. ${ }^{6}$ Equation 1.4 is a "band-pass" spectral regression of the long-run cointegrating relation (see Engle (1972) and Corbae, Ouliaris and Phillips (2002)). The basic idea is that the regression parameters vary with the frequency of the data being considered, giving rise to non-linear effects in the time-domain.

A constant is not necessary in equation 1.4 because, by construction, the business cycle components of the variables will have a zero mean. Table 2 presents the results for the basic equation, without allowing for asymmetric effects depending on the state of the business cycle, using a frequency range of $[1 / 6,1 / 3]$, or 6 to 32 quarters, for the business cycle.

Table 2. Exchange Rate Pass-Through Estimates Over the Business Cycle, 1980:3 2010:3

\begin{tabular}{|c|c|c|c|}
\hline Variable & Coefficient & Std. Err. & t-stat \\
\hline$f w p i_{t}$ & $\alpha=1.2891$ & 0.2250 & 5.7301 \\
\hline$e x r_{t}$ & $\lambda=-0.5176$ & 0.1845 & -2.8049 \\
\hline \multirow{2}{*}{ Restrictions } & \multicolumn{2}{|c|}{$\begin{array}{c}\text { Test for Significant Difference from Long-Run Pass Through } \\
\text { Null hypothesis - Restriction is binding }\end{array}$} \\
\cline { 2 - 4 } & \multicolumn{2}{|c|}{ t-Statistic } & p-value \\
\hline$\delta_{1}=0.70$ & 2.5000 & 0.0138 \\
\hline$\delta_{2}=-0.93$ & 2.0423 & 0.0433 \\
\hline
\end{tabular}

The parameter estimates suggest a structural change in the pass-through relationship over the business cycle. They imply that exchange rate pass-through is only 0.51 over the business cycle and significantly smaller than the long-run estimate of 0.93 . Moreover, variations in foreign wholesale prices have an even greater effect on domestic prices compared to the zero (or long-run) frequencies. This implies that the nominal exchange rate would need to be adjusted by even more to offset specific changes in the foreign wholesale price index.

It is also plausible for the degree of exchange rate pass-through to depend on the state of the business cycle, specifically whether the economy is in an upswing or a downswing. For example, during a robust expansion, importers may retain a greater proportion of the cost savings arising from a stronger exchange rate. ${ }^{7}$ To investigate this issue, we introduce a dummy variable $g_{a p}^{+}$that assumes a value of 1 if the output gap in the previous quarter is $\geq 1$ percent and 0 otherwise. Likewise, gap ${ }_{t-1}^{-}$takes the value of 1 if the output gap in the previous quarter is $\leq-1$ percent and 0 otherwise. The maintained prior,

\footnotetext{
${ }^{6}$ See Appendix $\mathrm{C}$ for a technical description of the cyclical extraction process.

${ }^{7}$ Note that the reverse argument does not apply. Specifically, amidst strong economic growth, a weaker exchange rate is unlikely to materialize, as it would further fuel inflationary pressures. Likewise, in weaker economic conditions, domestic inflationary pressures would normally be muted, and tighter monetary policy is unlikely in such circumstances.
} 
therefore, is that asymmetric pass-through effects can be detected only when the output gap exceeds one percent in absolute value. The regression equation is:

$$
c_{l}^{h}\left(I P I_{t}\right)=\delta_{1} c_{l}^{h}\left(E X R_{t}\right)+\delta_{2} c_{l}^{h}\left(F W P I_{t}\right)+\beta_{1} c_{l}^{h}(E X R) g a p_{t-1}^{+}+\beta_{2} c_{l}^{h}(E X R) g a p_{t-1}^{-}+\varepsilon_{t}
$$

The magnitude and statistical significance of the coefficients $\delta_{1}, \beta_{1}$, and $\beta_{2}$ provide an assessment of the asymmetric pass-through effects arising from the business cycle. Two asymmetric outcomes might be present:

(i) If the output gap at time $t-1$ is less than one in absolute terms, the variables $\mathrm{gap}_{t-1}^{+}$and $\mathrm{gap}_{t-1}^{-}$are zero. In this case, the coefficient $\delta_{1}$ is the impact of a 1 percent appreciation in the exchange rate on domestic import prices when the economy is near potential. We would expect pass-through to be relatively quick and complete in this case.

(ii) If the output gap at time $t-1$ is $\geq 1$ percent, $\delta_{1}+\beta_{1}$ measures the effect of a 1 percent appreciation on import prices during robust economic conditions. Should the economy enter into a recession with the output gap at $t-1<=$ 1 percent, however, the sum of $\delta_{1+} \beta_{2}$ measures the impact on import prices owing to a 1 percent appreciation of the exchange rate.

Table 3 reports the results, again for variations in the data between 6 and 32 quarters. The empirical results provide strong evidence in favor of asymmetric pass-through effects over the business cycle. ${ }^{8}$ Specifically, when actual GDP is above potential by at least one percent, a one percent appreciation in the nominal exchange rate results in a 0.26 percent fall in domestic import prices, compared to a 0.71 percent decline in domestic import prices when real GDP is near potential. While a stronger exchange rate reduces costs, importers pass on a smaller portion of the exchange related cost savings during a robust expansion phase.

\footnotetext{
${ }^{8}$ Note that $c_{l}^{h}\left(E X R_{t}\right) \cdot g a p_{t-1}^{-}$was omitted from the preferred model because it was found to be statistically insignificant in preliminary regressions. This finding suggests the presence of downward price stickiness in Singapore.
} 
Table 3. Asymmetric Pass-Through over the Business Cycle, 1980:3 - 2010:3

\begin{tabular}{|c|c|c|c|c|}
\hline \multicolumn{5}{|c|}{ Dependent Variable : $c_{l}^{h}\left(I P I_{t}\right)$} \\
\hline Variable & Coefficient & Std. Err. & t-stat & p-value \\
\hline$c_{l}^{h}\left(E X R_{t}\right)$ & $\delta_{1}=-0.7114$ & 0.1689 & -4.2117 & 0.000 \\
\hline$c_{l}^{h}\left(E X R_{t}\right) \bullet g a p_{t-1}^{+}$ & $\delta_{2}=0.4547$ & 0.2466 & 1.8442 & 0.067 \\
\hline$c_{l}^{h}\left(F W P I_{t}\right)$ & $\delta_{3}=1.2842$ & 0.2385 & 5.3846 & 0.000 \\
\hline \multicolumn{5}{|c|}{ Diagnostic Test/Fit of Model } \\
\hline Adjusted R-squared & \multicolumn{5}{|c|}{046} \\
\hline
\end{tabular}

\section{Second Stage Pass-Through}

\section{A. Analytical Framework}

Second-stage exchange rate pass-through considers the transmission of changes in import prices (expressed in domestic currency terms) to retail prices, and hence to inflation as measured by changes in the consumer price index.

The following long-run model expresses Singapore's consumer price index as a mark-up over domestic unit labor cost (ULC) and IPI:

$$
C P I_{t}=\alpha\left(U L C_{t}\right)^{\beta}\left(I P I_{t}\right)^{\gamma}
$$

As before, a logarithmic transformation is applied to equation 1.5 to obtain:

$$
c p i_{t}=\lambda+\beta u l c_{t}+\gamma i p i_{t}
$$

where

(i) $\lambda=\log (\alpha)$ and thus $\left(e^{\lambda}-1\right)$ is the retail mark-up over costs; and

(ii) $\beta$ and $\gamma$ are elasticities of the CPI with respect to ULC and IPI respectively.

Equation 1.6 captures the major sources of consumer price inflation in Singapore, namely: domestic cost pressures, as measured by ULC; and external price pressures, in the form of the domestic prices of imports

In the presence of highly competitive markets, mark-up should be only marginally positive in the long-run, since excess profit margins or losses are not expected to prevail. As such, consumer prices of goods and services should rise proportionately with cost increases for businesses to remain viable in the long-run. This is equivalent to the unit homogeneity constraint, i.e., $\beta+\gamma=1$. 


\section{B. Estimation Results}

Similar to the first stage, the ULC and CPI series in equation 1.6 were tested for nonstationarity and found to be consistent with the unit root hypothesis. The Johansen test affirmed the existence of a long-run relationship between these variables and the IPI. Equation 1.6 was therefore estimated using Johansen's VECM approach, using quarterly data for 1991:4 - 2007:4 (Table 4(a)).

Both the estimated elasticities $\beta$ and $\gamma$ are of the expected signs and are statistically significant. Moreover, the likelihood ratio test suggests that the sum of $\beta$ and $\gamma$ is not statistically different from 1 . The equation was therefore re-estimated with this constraint imposed, yielding the preferred long-run specification for consumer prices shown in Table 4(b).

Table 4. Long-Run Pass-Through to Consumer Prices, 1991:1-2007:4

(a) Unconstrained Estimates

\begin{tabular}{|c|c|c|c|}
\hline Variable & Coefficient & Std. Err. & t-stat \\
\hline$u c_{t}$ & $\beta=0.750$ & 0.237 & 3.163 \\
\hline$i p i_{t}$ & $\gamma=0.554$ & 0.177 & 3.128 \\
\hline Constant & $\alpha=-1.404$ & 1.771 & 0.793 \\
\hline \multicolumn{4}{|c|}{ LR Test for Coefficient Restrictions } \\
\hline Hypothesis & Chi-sq (1) & p-value \\
\hline $\mathrm{H}_{\mathrm{o}}: \beta+\gamma=1$ & 0.459 & $0.498^{1 /}$ \\
\hline
\end{tabular}

The null hypothesis of the restriction being binding is accepted.

(b) Constrained Estimates, $\beta+\gamma=1$

\begin{tabular}{|c|c|c|c|}
\hline Variable & Coefficient & Std. Err. & t-stat \\
\hline$u c_{t}$ & $\beta=0.575$ & 0.081 & 7.109 \\
\hline$i p i_{t}$ & $V=0.425$ & 0.081 & 5.253 \\
\hline constant & $\alpha=0.005$ & 0.010 & 0.506 \\
\hline
\end{tabular}

The short-run dynamics for second stage pass-through are modeled using a standard error correction model. Specifically, log changes in the consumer price index are driven by the deviation of the consumer price index from its long-run equilibrium value, as determined by the mark-up model, as well as changes in CPI, ULC and import prices. Changes in the output gap and its level are also included in the set of explanatory short-run variables to capture the state of the business cycle. The short-run equation is:

$$
\begin{aligned}
\Delta c p i_{t}= & \alpha_{0}+\alpha_{1}\left(\text { cpi }_{t-1}-0.575 \text { ulc }_{t-1}-0.425 i p i_{t-1}\right)+\sum_{i=0}^{k} \alpha_{2 i} \Delta u l c_{t-i}+\sum_{i=0}^{j} \alpha_{3 i} \Delta i p i_{t-i} \\
& +\sum_{i=0}^{l} \alpha_{4 i} \Delta c p i_{t-1-i}+\sum_{i=0}^{m} \alpha_{5 i} \text { gapi }_{t-i}+\sum_{i=0}^{n} \alpha_{6 i} \Delta g a p i_{t-i}+\varepsilon_{t}
\end{aligned}
$$


The number of lag terms is chosen using the standard "general-to-specific" modeling approach, yielding the preferred model estimates presented in Table 5.

Table 5. Second Stage Pass-Through, Error Correction Estimation 1991:1 - 2007:4

\begin{tabular}{|c|c|c|c|c|}
\hline \multicolumn{5}{|c|}{ Dependent Variable: $\Delta c p i_{t}$} \\
\hline Variable & Coefficient & Std. Err. & t-stat & p-value \\
\hline Error-correction term & $\alpha_{1}=-0.032$ & 0.008 & -4.243 & 0.000 \\
\hline$\Delta u / c_{\mathrm{t}-3}$ & $\alpha_{23}=0.026$ & 0.017 & 1.471 & 0.147 \\
\hline$\Delta u / c_{\mathrm{t}-5}$ & $\alpha_{25}=0.023$ & 0.016 & 1.484 & 0.143 \\
\hline$\Delta i p i_{\mathrm{t}}$ & $\alpha_{30}=0.061$ & 0.022 & 2.753 & 0.008 \\
\hline$\Delta i p i_{\mathrm{t}-1}$ & $\alpha_{31}=0.032$ & 0.019 & 1.723 & 0.090 \\
\hline gap $\mathrm{t}_{\mathrm{t}-1}$ & $\alpha_{51}=0.001$ & 0.000 & 5.962 & 0.000 \\
\hline$\Delta g a p$ & $\alpha_{60}=0.001$ & 0.000 & 5.514 & 0.000 \\
\hline \multicolumn{5}{|c|}{ Diagnostic Test/Fit of Model } \\
\hline Adjusted R-squared & \multicolumn{5}{|c|}{0.724} \\
\hline
\end{tabular}

Rolling regressions (with a fixed 8-year window) were used to evaluate the robustness of the results. The recursive Chow-test suggested a break in the parameters around 2000:3, and no break thereafter. As such, the short-run specification was re-estimated with a reduced sample period from 2000:3 to 2007:4 (Table 6).

Diagnostic tests indicate that all the key variables in this regression are significant at the 10 percent level or better and have the expected signs. Interesting, the change in the output gap variable, rather than the level of the output gap, affects domestic inflation outcomes. This suggests that inflationary pressures could emanate from the rapid closing of a negative output gap, even when the rate of resource utilization is below potential. ${ }^{9}$

Table 6. Short-Run Second Stage Pass-Through in Singapore, 2000:3-2007:4

\begin{tabular}{|c|c|c|c|c|}
\hline \multicolumn{5}{|c|}{ Dependent Variable : $\Delta c p i_{t}$} \\
\hline Variable & Coefficient & Std Err & $\boldsymbol{t}$-stat & $\boldsymbol{p}$-value \\
\hline Error correction term $^{1 /}$ & $\alpha_{1}=-0.063$ & 0.025 & -2.535 & 0.019 \\
\hline$\Delta u c_{t}$ & $\alpha_{20}=0.055$ & 0.028 & 2.002 & 0.058 \\
\hline$\Delta i p i_{t-1}$ & $\alpha_{31}=0.134$ & 0.034 & 3.954 & 0.001 \\
\hline$\Delta g a p_{t}$ & $\alpha_{60}=0.003$ & 0.001 & 4.678 & 0.000 \\
\hline$\Delta g a p_{t-3}$ & $\alpha_{63}=0.001$ & 0.000 & 1.707 & 0.102 \\
\hline \multicolumn{5}{|l}{ Diagnostics/Fit of Model } \\
\hline
\end{tabular}

${ }^{9}$ MAS (2006) shows that changes in the output gap contain more useful information on inflationary dynamics than the size of the output gap. 
Adjusted R-squared
\begin{tabular}{|l|l|}
\hline I" The long-run relationship, as estimated by the cointegrating equation, is assumed to remain unchanged, given the \\
small sample size.
\end{tabular}

A simulation involving a 1 percent shock to IPI was carried out to estimate the time path of second stage pass-through. For comparison purposes, the model was also simulated separately with a 1 percent ULC shock. Figure 1 shows the response profiles of the CPI to both of these shocks. As noted previously, first stage pass-through is complete by the sixth quarter after the onset of the shock. In contrast, the adjustment of consumer price index to its long-term equilibrium from the IPI shock is far more sluggish and protracted. Not only is the response smaller throughout the horizon, the pace of adjustment is also slower, particularly in the outer years.

\section{Figure 1. Response Profile of Consumer Price Index and IPI}

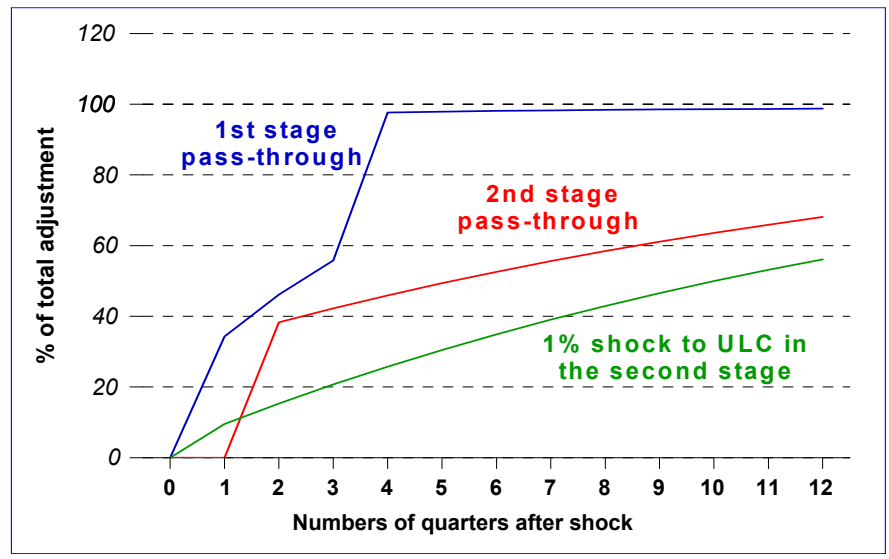

Note: The first stage pass-through profile is included as a basis of comparison. The magnitude of the impact is scaled in proportion to the respective long-run elasticity for comparability purposes, given that the overall long- run impact of the IPI and ULC shocks are less than $1 \%$.

\section{Implications of the Regression Results}

Two features of the domestic price mechanism can be inferred from the estimation results in Tables 4 and 6. First, the retail market appears to be highly competitive since (1) the constant term in the cointegrating equation, which proxies for the cost mark-up coefficient is marginally positive but statistically insignificant; and (2) the condition of unit cost homogeneity holds.

Second, on average, a 1 percent increase in ULC leads to a 0.58 percent increase in the CPI, compared with 0.42 percent for a similar increase in IPI. The larger ULC elasticity is consistent with the rising share of service items in Singapore's consumer price index basket from 39 percent in 1987-88 to 51 percent in 2003-04. A corollary is that the proportion of import costs in the overall consumer price index basket has declined in 
recent years, possibly reflecting the increased value-added of the nontraded sector to imported products.

The key result of the second stage analysis is the limited and protracted response of the consumer price index to movements in the IPI. Specifically, by the end of the second year, only about 60 percent of the long-run impact of the IPI shock is passed through to consumer prices. (Figure 1) According to the simulation, the subsequent adjustment slows significantly over time and becomes more drawn-out.

A number of factors could explain this result. First, the transmission of an import price shock to consumer prices is less direct than that of the first stage. The imported goods are first sold to the wholesalers, who then, in turn, distribute them to retailers. At each level of the supply chain, firms face different mark-up rates, menu costs and market conditions and so may not adjust prices at the same time. Second, strong competitive pressures across the supply chain could cap the extent of adjustment, as both wholesalers and retailers limit the import price pass-through to preserve market share. Third, at the retail level, the overall cost of a product consists of both the import cost and the nontradable components. A rise in the import cost would therefore translate into a smaller proportionate increase in the overall cost of the product. The ensuing impact on profit margins is thus likely to be less severe than that of an importer whose import costs represent the bulk of overall expenses. Faced with an increase in import cost, retailers could absorb some of the increase by using their profit margins as a buffer, given the competitive retail market. ${ }^{10}$ Significant "menu costs" could also lead to the same outcome. Lastly, the fact that the MAS attempts to dampen the impact of higher import prices on domestic prices may lower people's expectations of the permanency of any price shock emanating from the external sector, reducing its impact on the long-run path of the price level.

\section{Asymmetric Pass-Through Effects Over the Business Cycle}

Following the approach used in Section III (c), this paper also examines whether consumer prices respond asymmetrically to a given change in import prices over the business cycle. The regression for the cyclical dynamics in the CPI is:

$$
\begin{aligned}
c_{l}^{h}\left(C P I_{t}\right)= & \delta_{0}+\delta_{1} c_{l}^{h}\left(U L C_{t}\right)+\delta_{2} c_{l}^{h}\left(I P I_{t}\right)+\delta_{3} c_{l}^{h}\left(I P I_{t}\right) \bullet \operatorname{sign}_{1} \bullet \operatorname{gap}_{t-1}^{+} \\
& +\delta_{4} c_{l}^{h}\left(I P I_{t}\right) \bullet \operatorname{sign} n_{2} \bullet \operatorname{gap}_{t-1}^{-}+\varepsilon_{t}
\end{aligned}
$$

where, as before, the $c_{l}^{h}$ () operator denotes the cyclical components of the variables. The dummy variable $\operatorname{sign}_{1}$ equals 1 if the change in import prices in the current quarter is $\geq 0$, and 0 otherwise, while the other variable $\operatorname{sign}_{2}$ equals 1 if the change in import prices in

\footnotetext{
${ }^{10}$ This inference does not contradict the small mark-up estimated using the cointegrating framework, given that the latter is a characterization of the average pricing decision of firms in the long-run. Across the different phases of the business cycle, there will be significant variation in the actual mark-up, as firms adjust their product pricing to specific cyclical conditions.
} 
the current quarter is negative and 0 otherwise. The other two dummy variables, gap $_{t-1}^{+}$and $\mathrm{gap}_{t-1}^{-}$follow the definition in the first stage.

Given these definitions, four asymmetric outcomes with respect to import prices can occur, as outlined in Table 7. In particular, retailers are expected to pass on a larger proportion of the cost increases to consumers during periods of strong economic growth, when demand conditions are buoyant, and the price elasticity of demand is relatively low (Scenario A). In contrast, they are likely to absorb more of the import cost increases during a downturn to maintain sales (Scenario B). Retailers are likely to pass on more cost savings from the lower import cost to consumers during a slowdown to support demand (Scenario C). Conversely, they hold on to more cost savings when the economy is stronger (Scenario D).

Table 7. Possible Asymmetric Outcomes

\begin{tabular}{|c|c|c|c|}
\hline Scenario & $\begin{array}{c}\text { Import } \\
\text { Prices }\end{array}$ & $\begin{array}{c}\text { State of the } \\
\text { economy at } \mathrm{t}-1\end{array}$ & $\begin{array}{c}\text { Pass-Through to } \\
\text { CPI }\end{array}$ \\
\hline A & rise & gap $_{\mathrm{t}-1} \geq 1 \%$ & $\delta_{1}+\delta_{2}$ \\
\hline B & rise & gap $_{\mathrm{t}-1}<1 \%$ & $\delta_{1}$ \\
\hline C & fall & gap $_{\mathrm{t}-1} \leq-1 \%$ & $-\delta_{1}-\delta_{3}$ \\
\hline D & fall & gap $_{\mathrm{t}-1} \geq-1 \%$ & $-\delta_{1}$ \\
\hline
\end{tabular}

Table 8 contains the parameter estimates for equation 1.8 . The dummy variable $c_{l}^{h}\left(E X R_{t}\right) \square \operatorname{sign}_{2} \square g a p_{t-1}^{-}$is absent from the regression because it was found to be statistically insignificant in preliminary regressions. This suggests that the impact of a 1 percent decline in import prices on the consumer price index is not significantly different over the business cycle, possibly due to the general downward stickiness in retail prices. It is also plausible that during a downturn, consumers, faced with increased uncertainty in their future income streams, hold back their spending despite the price reductions.

Table 8. Second Stage Asymmetric Pass-Through 2000:3-2007:4

\begin{tabular}{|l|c|c|c|c|}
\hline \multicolumn{5}{|c|}{ Dependent Variable : $c_{l}^{h}\left(C P I_{t}\right)$} \\
\hline \multicolumn{1}{|c|}{ Variable } & Coefficient & Std. Err. & t-stat & p-value \\
\hline$c_{l}^{h}\left(I P I_{t}\right)$ & $\delta_{1}=0.075$ & 0.023 & 3.229 & 0.004 \\
\hline$c_{l}^{h}\left(I P I_{t}\right) \bullet$ sign $_{1} \bullet g a p_{t-1}^{+}$ & $\delta_{2}=0.164$ & 0.078 & 2.099 & 0.048 \\
\hline$c_{l}^{h}\left(U L C_{t-3}\right)$ & $\delta_{43}=0.028$ & 0.019 & 1.438 & 0.165 \\
\hline$c_{l}^{h}\left(C P I_{t-1}\right)$ & $\delta_{50}=0.597$ & 0.116 & 5.136 & 0.000 \\
\hline \multicolumn{5}{|c|}{0.876} \\
\hline Adjusted R-squared & Diagnostic Test/Fit of Model \\
\hline
\end{tabular}


An asymmetric outcome arises, however, in the event of an increase in import prices. Given strong economic growth, a 1 percent increase in import prices leads to a 0.24 percent increase in consumer prices, or equivalently, 60 percent of the long-term impact in the same quarter. Over the other phases of the business cycle, consumer prices rise by only 0.08 percent approximately.

These findings imply that retailers pass on a greater amount of an import cost increase to consumers during robust economic conditions. The speed of adjustment conditional on the asymmetric impact is also noticeably faster than that of the average adjustment. The latter shows that about 60 percent of the long-run impact is passed on to consumer prices by the end of the second year. (Figure 1) In comparison, the cyclical analysis shows that the same amount of pass-through is completed within the first quarter of the onset of the shock.

\section{Cumulative Impact Of The Two Stages And Implications For Monetary POLICY}

The empirical models of the first and second stage pass-through effects, as presented in Tables 1 and 6, respectively, are now combined to obtain the overall exchange rate passthrough in the Singapore economy. Specifically, the model has two ECM specifications (coefficients on lagged change variables are not shown):

$$
\begin{aligned}
& \Delta i p i_{t}=\hat{\beta}_{0}-0.186\left(\text { ipi }_{t-1}-0.729 f w p i_{t-1}+e x r_{t-1}\right) \\
& \Delta c p i_{t}=\hat{\alpha}_{0}-0.063\left(c p i_{t-1}-0.575 u l c_{t-1}-0.425 i p i_{t-1}\right)
\end{aligned}
$$

Two simulations are applied to the system to estimate the price transmission effects. First, a simulation was performed to trace out the cumulative exchange rate pass-through to domestic consumer price index inflation. The model suggests that a 1 percent appreciation in the exchange rate leads to a 0.1 percent decline in the consumer price index by the

fourth quarter, which is equivalent to around 25 percent of the full pass-through. ${ }^{11}$ By the end of the second year, the cumulative impact on consumer price index is 0.22 percent below baseline, or about 50 percent of the overall pass-through. In the outer years, the pace of adjustment becomes more sluggish owing to the muted second stage pass-through. (Figure 2)

The extent of Singapore's exchange rate pass-through to domestic inflation appears similar to that of other developed countries, owing to the protracted second stage. Gagnon and Ihrig (2004), for example, estimate the pass-through for a broad set of industrial countries to be roughly at 0.2 percent for a 1 percent change in the exchange rate. Liu and

\footnotetext{
${ }^{11}$ The first stage pass-through is complete. Hence, in the long-run, consumer price index would be 0.42 percent below baseline for a 1 percent appreciation in the exchange rate. A 0.1 percent decline in the consumer price index is therefore equivalent to around 25 percent of the full impact.
} 
Tsang (2008) also obtain similar results for Hong Kong-exchange rate pass-through is about 0.1 in the short run and 0.2 in the medium term.

The second simulation illustrates the effectiveness of the exchange rate as a filter for imported inflation. A 1 percent increase in the foreign price of imports is introduced into the combined model. Ultimately, domestic import costs increase by 0.76 percent. It follows that the exchange rate needs to be revalued by 0.76 percent to fully offset this increase.

This revaluation is now introduced into the simulation in the quarter following the foreign price shock. And a separate simulation with the S\$NEER held constant is performed to isolate the filtering impact of the exchange rate. Figure 3 shows the responses of IPI and the CPI to these shocks. The impact of the foreign price shock on IPI is dampened significantly by the exchange rate appreciation. Moreover, the domestic consumer price index is relatively insulated from the foreign price shock, reaching a peak of only 0.1 percent above baseline into the second year of the impact. Consumer price increases are staggered over time owing to sluggish second stage pass-through.

It is also useful to examine the asymmetric pass-through effects. Suppose the exchange rate is unchanged, but an increase in foreign prices causes domestic import price to rise by 1 percent. Given robust economic growth, retailers would pass on a larger extent of the cost increase to consumers, leading to a 0.24 percent increase in the consumer price index in the short run. In comparison, the pass-through results that capture the average pricing behavior across all episodes suggest a more muted second stage pass-through of only 0.13 percent.

Figure 2. Percentage Deviation in Consumer Price Index for a One Percent Appreciation in the Exchange Rate

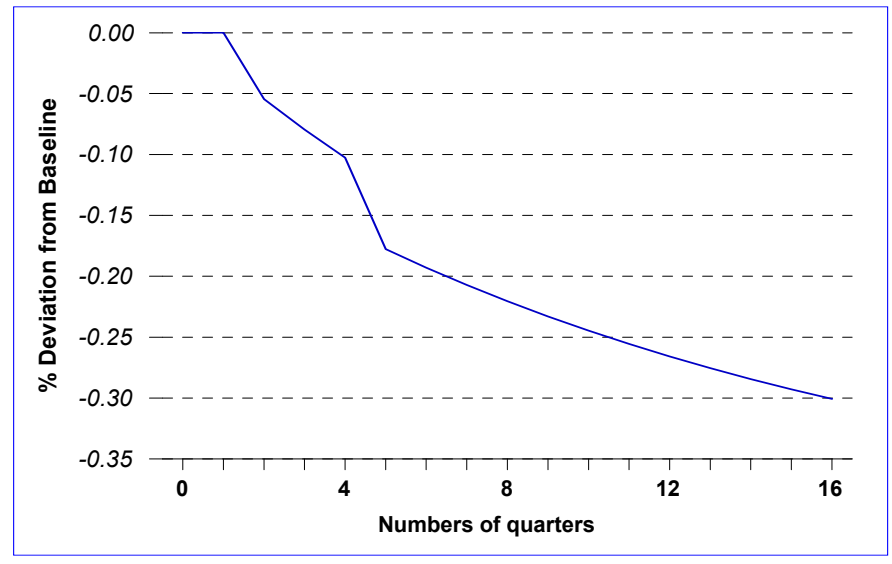




\section{Figure 3. Percentage Deviation in IPI and Consumer Price Index for a One Percent Increase in FWPI}

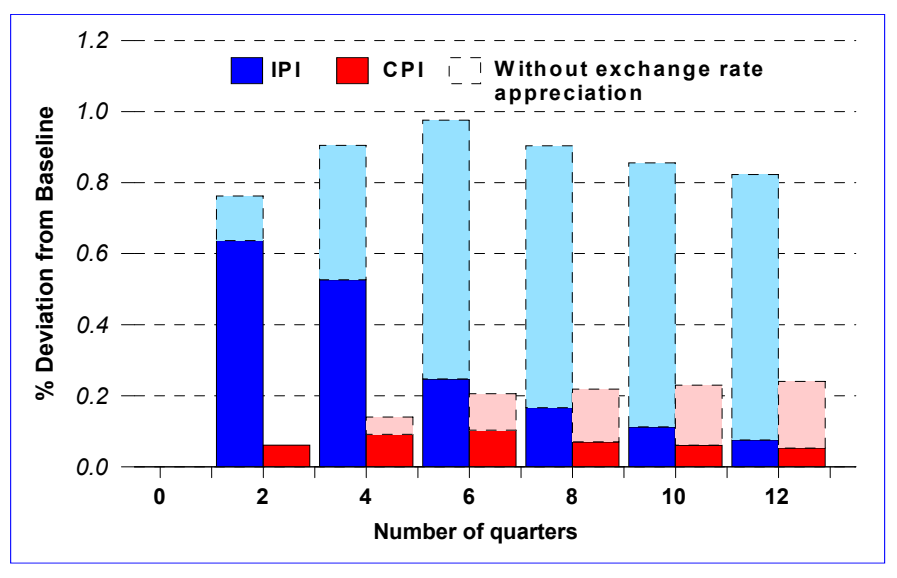

The first stage pass-through effects are also asymmetric during a cyclical expansion. Specifically, a 1 percent appreciation would lead to a 0.24 percent decline in domestic import prices in this instance, compared to a larger 0.34 percent decline in the average pass-through outcome. In this case, an even stronger monetary response is needed to counteract the overall cyclical exchange rate pass-through effects. To put it more succinctly, monetary policy has to "lean against the wind" during a robust cyclical expansion that is accompanied by an increase in foreign inflationary pressures. ${ }^{12}$

\footnotetext{
${ }^{12}$ It is worth highlighting that these implications for monetary policy are drawn solely from the exchange rate pass-through effects. Exchange rate movements also affect domestic prices through their impact on export earnings, which is not examined in this paper. A general equilibrium macro econometric model would be needed to assess the overall impact of the exchange rate on consumer prices. To maintain mediumterm price stability and sustained economic growth, any setting of exchange rate policy would need to take into account the impact on growth and inflation arising from both channels.
} 


\section{Conclusion}

This paper provides a detailed analysis of exchange rate pass-through for Singapore. The results suggest that changes in the exchange rate are quickly reflected in domestic import prices at the first stage, and that the pass-through to import prices is complete by the end of the sixth quarter. In comparison, the second stage effects on the consumer price index are more drawn-out, resulting in a fairly low exchange rate pass-through. This assessment is not unique to Singapore, as econometric evidence for many other industrial countries also points to subdued pass-through effects.

A significant portion of the paper has been devoted to investigating the presence of asymmetric pass-through effects over the business cycle. To the best of our knowledge, such asymmetries have not been studied in the pass-through literature, even though the price-setting behaviour of firms has been frequently documented to depend on macroeconomic conditions. This paper contributes to the literature by providing an empirical framework for assessing the asymmetric pass-through effects over the business cycle.

Our results find significant evidence of such asymmetries in Singapore. Specifically, importers pass on a smaller share of the cost savings arising from a stronger exchange rate amidst robust economic growth, than when costs increase as a result of a weaker exchange rate during a downturn. At the second stage, retailers would tend to be more aggressive in passing on import cost increases amidst strong economic growth.

Two inferences for Singapore's exchange rate policy emerge from the empirical analysis. First, the nominal exchange rate, in itself, remains an effective tool in mitigating external price pressures, as importers ultimately pass on the full cost savings arising from a stronger exchange rate. Second, in view of the asymmetric pass-through effects, monetary policy in Singapore may need to "lean strongly against the wind" during robust cyclical expansions accompanied by increases in import costs. The case for doing so is made stronger by the fact that Singapore's business cycle is positively related to the global business cycle and hence rises in foreign prices. 


\section{REFERENCES}

Bailliu, J. and E. Fujii, 2004, "Exchange Rate Pass-Through and the Inflationary Environment in Industrialized Countries: An Empirical Investigation," Bank of Canada Working Paper 2004-21, Bank of Canada.

Campa, J. and L. Goldberg, 2005, "Exchange Rate Pass-Through into Import Prices," Review of Economics and Statistics, 87(4), pp. 679-690.

Campa, J., L. Goldberg, and J. Gonzalez-Minguez, 2005, "Exchange Rate Pass-Through to Import Prices in the Euro Area," Banco De Espana Working Paper 0538, Banco De Espana.

Choudhri, E. and D. Hakura, 2006, "Exchange Rate Pass-Through to Domestic Prices: Does the Inflationary Environment Matter?' Journal of International Money and Finance, 25(4), pp. 614-639.

Corbae, D. and S. Ouliaris, 2006, "Extracting Cycles from Nonstationary Data," in Econometric Theory and Practice: Frontiers of Analysis and Applied Research, edited by Corbae, D, Durlauf, S and B Hansen, Cambridge University Press, pp. 167-178.

Corbae, D., S. Ouliaris and P.C.B. Phillips, 2002, "Band Spectral Regression with Trending Data," Econometrica, 70, pp. 1067-1109.

Cunningham, A. and A. Haldane, 2002, "The Monetary Transmission Mechanism in the United Kingdom: Pass-Through and Policy Rules," in Monetary Policy: Rules and Transmission Mechanisms, edited by Loayza, N and K. Schmidt-Hebbel, Santiago, Chile: Banco Central de Chile.

Dornbusch, R., 1987, "Exchange rates and Prices," American Economic Review, 77, pp. 93-106.

Devereux, M. and J. Yetman, 2002, "Price Setting and Exchange Rate Pass-Through: Theory and Evidence," in Price Adjustment and Monetary Policy, conference proceedings, Bank of Canada, Ottawa: Bank of Canada.

Dwyer, J. and K. Leong, 2001, "Changes in the Determinants of Inflation in Australia," Research Discussion Paper 2001-02, Reserve Bank of Australia Economic Group.

Engel, C., 2002, "Expenditure Switching and Exchange-Rate Policy," NBER Macroeconomics Annual, pp. 231-72.

Enzler, J., et. al., 2005, "Two Decades of Macromodelling at the MAS," MAS Staff Paper No. 39, Monetary Authority of Singapore. 
Gagnon, J. and J. Ihrig, 2004, "Monetary Policy and Exchange Rate Pass-Through," International Journal of Finance and Economics, 9, pp. 315-38.

Ihrig, J., M. Marazzi, and A. Rothenberg, 2006, "Exchange Rate Pass-Through in the G-7 Countries," Board of Governors of the Federal Reserve System International Finance Discussion Papers, 851.

Johansen, S., 1988, "Statistical Analysis of Cointegrating Vectors," Journal of Economic Dynamics and Control, Vol. 12, pp. 231-54.

Khor, H. E., E. Robinson, and J. Lee, 2004, "Managed Floating and Intermediate Exchange Rate Systems: The Singapore Experience," MAS Staff Paper, No. 37, Monetary Authority of Singapore.

Liu, L. and A. Tsang, 2008, "Exchange Rate Pass-Through to Domestic Inflation in Hong Kong," Hong Kong Monetary Authority Working Paper, 02/2008.

Marazzi, M. and N. Sheet, 2007, "Declining Exchange Rate Pass-Through to US Import Prices: The Potential Role of Global Factors," Journal of International Money and Finance, 26, pp. 924-47.

Mishkin, F, 2008, "Exchange Rate Pass-Through and Monetary Policy," Speech to the Norges Bank Conference on Monetary Policy, Oslo, Norway, 7; available at http://www.federalreserve.gov/newsevents/speech/mishkin20080307a.htm.

Monetary Authority of Singapore, 2001a, "Singapore's Exchange Rate Policy," MAS Monograph Series.

Monetary Authority of Singapore, 2001b, "Box Item 3.1: Modeling Inflation Dynamics in Singapore," Economics Department Quarterly Bulletin, Volume III Issue 1, pp.35-37.

Monetary Authority of Singapore, 2001c, "Box Item 3.1: Investigating the Exchange Rate Pass-Through Relationship in Singapore," Economics Department Quarterly Bulletin, Volume III Issue 3, pp.47-54.

Monetary Authority of Singapore, 2006, "Box Item D: Assessing the relationship between Output Gap and Inflation," Macroeconomic Review, Vol. V, No. 1, pp. 55-58.

Monetary Authority of Singapore, 2007, "Chapter 2.1: Consumer Price Developments," Macroeconomic Review, Volume VI Issue 2, pp. 26-31.

Monetary Authority of Singapore, 2008a, "Box C: A Stylized Representation of the Price Transmission Mechanism in Singapore," Macroeconomic Review, Volume VII Issue 1, pp. $69-70$. 
Monetary Authority of Singapore, 2008b, "Special Feature A: An Empirical Analysis of Exchange Rate Pass-Through in Singapore," Macroeconomic Review, Volume VII Issue 2, pp. 76-85.

Olivei, G., 2002, "Exchange Rates and the Prices of Manufacturing Products Imported into the United States," New England Economic Review, First Quarter 2002, pp. 3-18.

Taylor, J., 2000, "Low Inflation, Pass-Through and the Pricing Power of Firms," European Economic Review, June Volume 44 Issue 7, pp. 1389-1408. 


\section{APPENDIX A. Series Descriptions and Data Sources}

\begin{tabular}{|c|c|c|c|}
\hline Series & $\begin{array}{l}\text { Series } \\
\text { Name }\end{array}$ & Description & Source \\
\hline $\begin{array}{l}\text { S\$NEER } \\
\text { (also } \\
\text { denoted } \\
\text { as EXR.) }\end{array}$ & $\begin{array}{l}\text { Singapore } \\
\text { Dollar } \\
\text { Nominal } \\
\text { Effective } \\
\text { Exchange } \\
\text { Rate }\end{array}$ & $\begin{array}{l}\text { The S } \$ N E E R \text { is weighted by the share of } \\
\text { Singapore's major trading partners in total } \\
\text { imports. }\end{array}$ & $\begin{array}{l}\text { Authors' } \\
\text { calculation. The } \\
\text { countries and their } \\
\text { weights in the } \\
\text { S\$NEER are not } \\
\text { published. }\end{array}$ \\
\hline $\mathrm{CPI}$ & $\begin{array}{l}\text { Consumer } \\
\text { Price Index }\end{array}$ & $\begin{array}{l}\text { The index measures the change in the prices of } \\
\text { fixed basket of goods and services commonly } \\
\text { purchased by the majority of households. The } \\
\text { weights of the items are based on the results of } \\
\text { the latest Household Expenditure Survey, } \\
\text { conducted once every five years. The base } \\
\text { year period of the current consumer price index } \\
\text { is } 2004 \text {. }\end{array}$ & $\begin{array}{l}\text { Department of } \\
\text { Statistics, Ministry } \\
\text { of Trade and } \\
\text { Industry, } \\
\text { Singapore. }\end{array}$ \\
\hline$\overline{I P I}$ & $\begin{array}{l}\text { Import Price } \\
\text { Index }\end{array}$ & $\begin{array}{l}\text { The IPI measures the price changes of } \\
\text { Singapore's imports in Singapore dollar terms. } \\
\text { Prices are valued at CIF (cost, insurance and } \\
\text { freight) and are obtained monthly from major } \\
\text { importers. The list of items and weighting } \\
\text { patterns are derived from import statistics for } \\
\text { the year } 2005 \text {. The base year period of the } \\
\text { current IPI is } 2006 \text {. }\end{array}$ & $\begin{array}{l}\text { Department of } \\
\text { Statistics, Ministry } \\
\text { of Trade and } \\
\text { Industry, } \\
\text { Singapore. }\end{array}$ \\
\hline FWPI & $\begin{array}{l}\text { Foreign } \\
\text { Wholesale } \\
\text { Price Index }\end{array}$ & $\begin{array}{l}\text { The Foreign Wholesale Price Index (FWPI) is a } \\
\text { weighted index of producer/wholesale price } \\
\text { indices of Singapore's major trading partners. } \\
\text { The weights are determined by their shares in } \\
\text { Singapore's total imports. }\end{array}$ & $\begin{array}{l}\text { Authors' } \\
\text { calculation. The } \\
\text { countries and their } \\
\text { weights in the } \\
\text { FWPI are not } \\
\text { published. }\end{array}$ \\
\hline ULC & $\begin{array}{l}\text { Unit Labor } \\
\text { Cost }\end{array}$ & $\begin{array}{l}\text { Total labor cost per unit of real output. Total } \\
\text { labor cost comprises wages and salaries, } \\
\text { benefits, CPF contributions by employers, } \\
\text { foreign workers' levy and skill development } \\
\text { levy. The base year period of the current ULC } \\
\text { series is } 2000 \text {. }\end{array}$ & $\begin{array}{l}\text { Department of } \\
\text { Statistics, Ministry } \\
\text { of Trade and } \\
\text { Industry, } \\
\text { Singapore. }\end{array}$ \\
\hline
\end{tabular}




\section{APPENDIX B. Unit Root and Cointegration Results}

Table B.1. First Stage Pass-Through: Unit Root Tests, 1980:3-2010:3

\begin{tabular}{|c|c|c|c|c|}
\hline \multicolumn{5}{|c|}{ Null Hypothesis: ADF (unit root); FD (stationarity) } \\
\hline Variable & ADF t-statistic & p-value & FD t-statistic & p-value \\
\hline ipi $_{t}$ & -2.1968 & 0.2086 & -10.693 & 0.0000 \\
\hline fwpi $_{t}$ & -0.5617 & 0.8737 & 74.734 & 0.0000 \\
\hline exr $_{t}$ & -2.233 & 0.165 & 60.310 & 0.0000 \\
\hline
\end{tabular}

All the series are nonstationary based on the ADF and FD tests.

Table B.2. First Stage Pass-Through: Cointegration Rank Tests

\begin{tabular}{|c|c|}
\hline \multicolumn{2}{|c|}{ Trend Assumption: Linear Deterministic Trend } \\
\hline Lags interval (in first differences) & 1 to 2 \\
\hline $\begin{array}{c}\text { Trace test indicates } \\
1 \text { cointegrating equation at the 0.05 level }\end{array}$ & $\checkmark$ \\
\hline $\begin{array}{c}\text { Max-eigenvalue test indicates } \\
1 \text { cointegrating equation at the 0.05 level }\end{array}$ & $\checkmark$ \\
\hline Akaike information criterion in Rank 1 VECM & -17.701 \\
\hline Schwarz criterion in Rank 1 VECM & -17.034 \\
\hline
\end{tabular}

The Johansen cointegration test suggests the existence of a long-run relationship between the three variables. The result is confirmed by the FD test, which assumes cointegration under the null ( $\mathrm{p}$-value is 0.09 ).

Table B.1. Second Stage Pass-Through: Unit Root Tests, 1991:1 - 2007:4

\begin{tabular}{|c|c|c|c|c|}
\hline \multicolumn{5}{|c|}{ Null Hypothesis: ADF (unit root); FD (stationarity) } \\
\hline Variable & ADF t-stat & One-sided p-values & FD t-statistic & p-value \\
\hline$c p i_{t}$ & -0.468 & 0.892 & 8.2960 & 0.0000 \\
\hline$u l c_{t}$ & -0.962 & 0.764 & 5.5977 & 0.0000 \\
\hline$i p i_{t}$ & -2.145 & 0.228 & -3.3314 & 0.0012 \\
\hline
\end{tabular}

All the series are nonstationary based on the ADF and FD test. 
Table B.2. Second Stage Pass-Through: Cointegration Rank Tests

\begin{tabular}{|c|c|}
\hline \multicolumn{2}{|c|}{ Trend Assumption: Linear Deterministic Trend } \\
\hline Lags interval (in first differences) & 1 to 2 \\
\hline $\begin{array}{c}\text { Trace test indicates } \\
\text { 1 cointegrating equation at the 0.05 level }\end{array}$ & $\checkmark$ \\
\hline $\begin{array}{c}\text { Max-eigenvalue test indicates } \\
\text { 1 cointegrating equation at the 0.05 level }\end{array}$ & $\checkmark$ \\
\hline Akaike information criterion in Rank 1 VECM & -18.341 \\
\hline Schwarz criterion in Rank 1 VECM & -17.147 \\
\hline
\end{tabular}

The Johansen cointegrating test suggests the existence of a long-run relationship between the three variables. The FD test confirms the presence of Cointegration ( $\mathrm{p}$ value $=$ $0.1312)$. 


\section{APPENDIX C. Extracting Business Cycles from Non-Stationary Series}

The business cycle components of the time-series, which were all found to possess unit roots, were calculated using the approximation to the ideal band pass filter proposed in Corbae and Ouliaris (2006).

If one accepts the standard definition of the business cycle as fluctuations in the level of a series within a specified range of periodicities, then the ideal filter is simply a band-pass filter that extracts components of the time series with periodic fluctuations those frequencies. It can be shown that the exact band-pass filter is a double-sided moving average of infinite order, and with known weights.

Many approximations to the ideal band pass filter have been suggested in the literature, with perhaps the Hodrick-Prescott (1980) being the most popular. In this section we outline an alternative, frequency domain, procedure for approximating the ideal filter that overcomes some of the shortcomings of time-domain based filters such as the HodrickPrescott filter.

Assume that $x_{t}(t=1 \ldots, n)$ is an observable time series generated by:

$$
x_{t}=\Pi_{2}^{\prime} z_{t}+\tilde{x}_{t}
$$

where $z_{t}$ is a $p+1$-dimensional deterministic sequence and $\tilde{x}_{t}$ is a zero mean time series. The series $x_{t}$ has both a deterministic component involving the sequence $z_{t}$ and a stochastic (latent) component $\tilde{x}_{t}$.

Corbae and Ouliaris (2006) make the following, fairly standard, assumptions about $z_{t}$ and $\tilde{x}_{t}$.

Assumption 1: $z_{t}=\left(1, t, \ldots, t^{p}\right)^{\prime}$ is a $p^{\text {th }}$ order polynomial in time.

Assumption 2: $\widetilde{x}_{t}$ is an integrated process of order one (I(1) process) satisfying $\Delta \widetilde{x}_{t}=$ $v_{t}$, initialized at $t=0$ by any $O_{p}(1)$ random variable. We assume that $v_{t}$ has a Wold

representation $v_{t}=\sum_{j=0}^{\infty} c_{j} \xi_{t-j}$ where $\xi_{t}=i i d\left(0, \sigma^{2}\right)$ with finite fourth moments and coefficients $c_{j}$ satisfying $\sum_{j=0}^{\infty} j^{2}\left|c_{j}\right|<\infty$. The spectral density of $v_{t}$ is $f_{v v}(\lambda)>0, \forall \lambda$.

Assumption 2 suffices for partial sums of $v_{t}$ to satisfy the functional law a univariate Brownian motion $n^{-1 / 2} \sum_{i=1}^{[m]} v_{t} \stackrel{d}{\longrightarrow} B(r)=B M\left(\sigma^{2}\right)$ with variance $\sigma^{2}=2 \pi f_{v v}(0)$, and where $\stackrel{d}{\longrightarrow}$ is used to denote weak convergence of the associated probability measures as the sample size $n \rightarrow \infty$. We now state the result that motivates the new filtering procedure. 
Lemma B (Corbae, Ouliaris, and Phillips (2002)) Let $\tilde{x}_{t}$ be an I(1) process satisfying Assumption 2. Then, the discrete Fourier transform of $\tilde{x}_{t}$ for $\lambda_{s} \neq 0$ is given by:

$$
\omega_{\tilde{x}}\left(\lambda_{s}\right)=\frac{1}{1-e^{i \lambda_{s}}} \omega_{v}\left(\lambda_{s}\right)-\left(\frac{e^{i \lambda_{s}}}{1-e^{i \lambda_{s}}}\right) \frac{\tilde{x}_{n}-\tilde{x}_{0}}{n^{1 / 2}}
$$

where the discrete Fourier transform (dft) of $\left\{a_{t} ; t=1, \ldots, n\right\}$ is written

$$
\omega_{\tilde{x}}\left(\lambda_{s}\right)=\frac{1}{\sqrt{n}} \sum_{t=1}^{n} a_{t} e^{i \lambda_{t}}
$$

and $\left\{\lambda_{s}=\frac{2 \pi s}{n}, s=0,1, \ldots, n-1\right\}$ are the fundamental frequencies.

Equation (2) implies that the discrete Fourier transforms of an I(1) process are not asymptotically independent across the fundamental frequencies. They are frequency-wise dependent by virtue of the component $n^{-1 / 2} \tilde{x}_{n}$, which produces a common leakage into all frequencies $\lambda_{s} \neq 0$, even as $n \rightarrow \infty$. This result suggests that in the presence of I(1) variables, any frequency domain estimate of the "cyclical" component of a time series (e.g., real GDP) could be badly distorted.

Corbae and Ouliaris (2006) suggest a "frequency domain fix" to this problem, derived from equation 1.11 . Note that

$$
w_{\left(\frac{t}{n}\right)}\left(\lambda_{s}\right)=\frac{-1}{\sqrt{n}}\left(\frac{e^{i \lambda_{s}}}{1-e^{i \lambda_{s}}}\right)
$$

by Lemma B of Corbae, Ouliaris, and Phillips (2002). Thus, even for the case where there is no deterministic trend in equation 1.10, it is clear from the second term in equation 1.11 that the leakage from the low frequency can be removed by detrending the series in the frequency domain.

Using Lemma A of Corbae, Ouliaris, and Phillips (2002), one can show that Hannan's (1970) frequency domain estimator of $\left[\tilde{x}_{n}-\tilde{x}_{0}\right]$ will converge to zero under the null hypothesis of stationarity. In particular,

$$
\sqrt{n} \tilde{\beta}_{w\left(\frac{t}{n}\right)}^{f} \stackrel{d}{\longrightarrow} N\left(0, \varphi^{2}\right)
$$

where $\varphi^{2}=144 \frac{\int_{B_{A}^{c}} f_{1}(\omega) f_{v v}(\omega) f_{1}(\omega)^{*} d \omega}{\left|1-e^{i \lambda_{s}}\right|^{2}}$ and $f_{1}(\omega)=\frac{e^{i \omega}}{e^{i \omega}-1}$, so that $\tilde{\beta}_{w\left(\frac{t}{n}\right)}^{f} \stackrel{p}{\longrightarrow} 0$ under the null hypothesis of stationarity (henceforth the FD test). Note that if $\tilde{x}$ is a non- 
stationary process, then $\sqrt{n} \tilde{\beta}_{w\left(\frac{t}{n}\right)}^{f}$ will mimic $\left[\tilde{x}_{n}-\tilde{x}_{0}\right]$ as $n \rightarrow \infty$, yielding a consistent test of the stationarity hypothesis ( including the null of cointegration, using the estimated residuals from a long-run cointegrating regression).

The manner in which the FD test works can be inferred from a graph of the Discrete Fourier transformation of a time trend when the "non-business cycle" frequencies (i.e., those outside of the $[1 / 16,1 / 3]$ range) are removed. It is clear from the graph that the DFT of the filtered time trend is symmetrical around $\pi / 2$ and contains significant peaks near the zero (or long-run) frequency and at the $\pi$ frequency. The FD test determines whether the same features are present in the level of the filtered series using a standard $t-$ statistic arising from an OLS regression of the filtered series against the filtered (normalized) time trend.

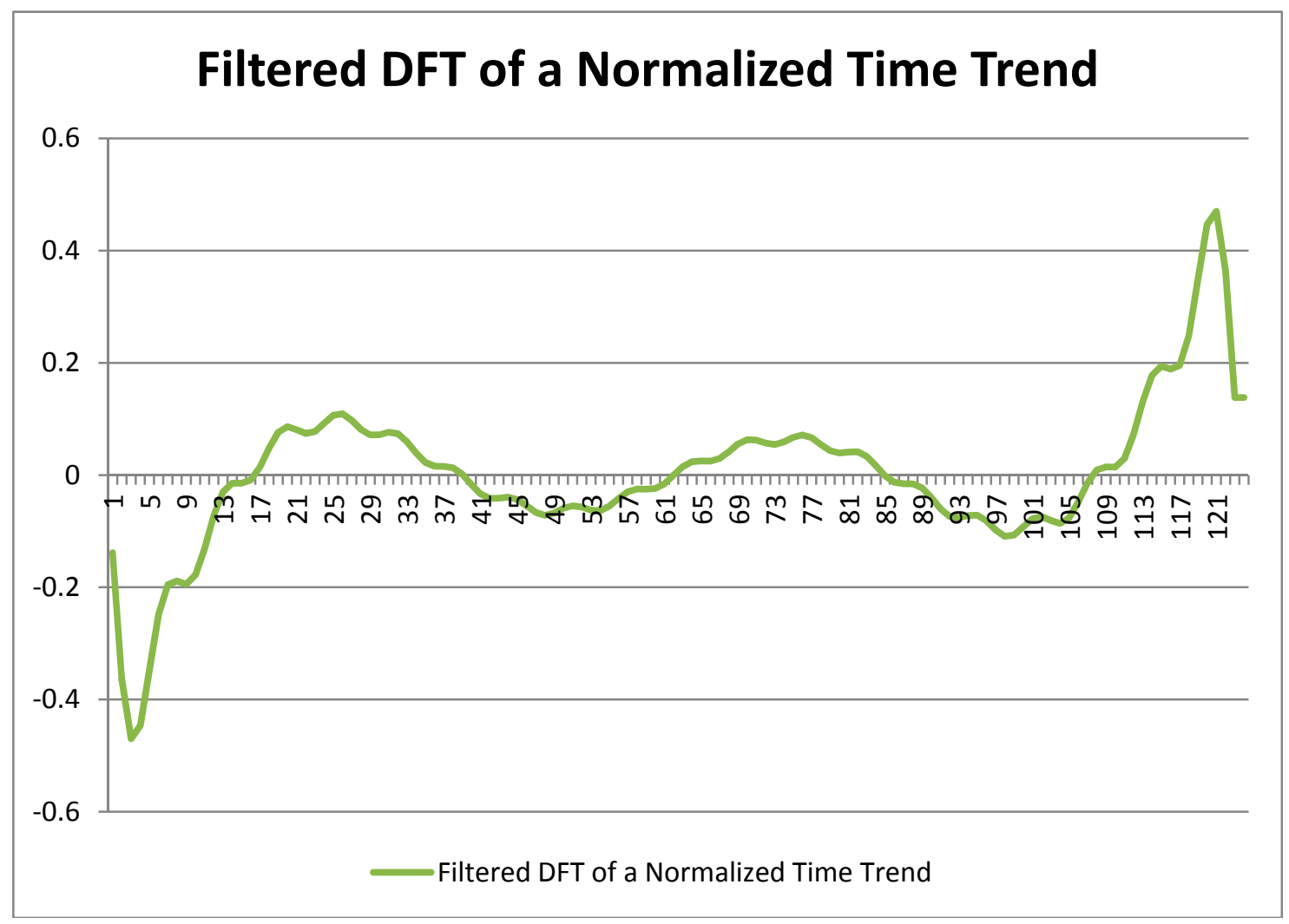

